\title{
АНАТОЛИЙ СОБЕННИКОВ
}

0000-0002-8202-4043

Военный институт Железнодорожных войск

и военных путей сообщения

Кафедра иностранных и русского языков

198511 Петергоф

ул. Суворовская, 1

assoben52@mail.ru

\section{В ТЕНИ А. П. ЧЕХОВА: Е. М. ШАВРОВА КАК ПИСАТЕЛЬ ВТОРОГО РЯДА}

\section{IN CHEKHOV'S SHADOW: YELENA SHAVROVA AS A "SECOND-CLASS" WRITER}

Статья посвящена творческой связи А. П. Чехова с Е. М. Шавровой, произведения которой он редактировал и продвигал в печать. Шаврова прислушивалась к советам Чехова: сокращала описания, убирала фрагменты, рассчитанные на эффект. Отмечается усвоение художественных принципов Чехова молодым писателем: повествование в «духе и тоне героя», замена внешней событийности психологическим состоянием персонажа, открытые финалы. Шаврову, как и Чехова, интересовала гендерная проблематика. После смерти писателя Шаврова уходит из литературы.

Ключевые слова: А. П. Чехов, Е. М. Шаврова, редактирование, событийность, гендерная психология.

The article is devoted to Anton Chekhov's creative connection with Yelena Shavrova, for whom he edited her works and helped her have them published. Shavrova followed Chekhov's advice: she shortened descriptions and removed fragments calculated for effect. The young writer indeed absorbed Chekhov's artistic principles: narrating "in the spirit and tone of the character", relinquishing external eventfulness for the sake of focusing on the characters' psychological states, open endings. Like her mentor, Shavrova was also interested in gender issues. After Chekhov's death, Shavrova gave up literary activities.

Translated from the Russian by Marta Kaźmierczak

Keywords: Anton Chekhov, Yelena Shavrova, editing, eventfulness, gender psychology. 
Шаврова Елена Михайловна (в замужестве Юст) автор рассказов и повестей, переводчица, певица, актриса. Летом 1889 г., отдыхая с сестрами в Ялте под присмотром англичанки, 15-летняя Шаврова сумела без всякой протекции познакомиться с А. П. Чеховым и попросила уже известного писателя прочесть ее рассказ Софка. Рассказ был отредактирован Чеховым, переслан А. С. Суворину и опубликован в газете «Новое время»1. С этого времени писатель стал постоянным наставником Шавровой в ее литературных занятиях (она много лет называла его в письмах «cher maître»): правил и продвигал в печать ее сочинения, давал профессиональные советы. Всего известно 130 писем Шавровой ${ }^{2}$ и 69 ответных писем Чехова.

Литературное наследство Шавровой невелико, всего было опубликовано около 20 рассказов и повестей, в том числе в «Новом времени» (Птички певчие, 1889, 25 ноября; Замуж, прил. к «Новому времени» 1991, 15 янв.; Невесты, 1891, 18 янв.; У гадалки, 1891, 24 мая; Маленькая барышня, 1892, 29 февр.), в «Московской иллюстрированной газете» (В цирке. (Горбун) 1892, 22 марта); в журналах «Артист» (Маркиза, 1894, № 38), «Русская мысль» (Бабье лето, 1896, № 3), Жена цезаря, (1897, № 12). Маркиза была также опубликована в сб. Под черемухой (Москва, 1916. с. 3-17). Узость тематики прозы Шавровой (первая влюбленность, замужество, ревность, положение женщины в семье и в браке, неравенство полов) была отмечена А. Чеховым: «Не пора ли вам, сударыня, расширить поле Ваших наблюдений? Вы почти в каждом рассказе повторяете так или иначе мотивы Бабьего лета, между тем мирок, Вами изображаемый, давно уже исчерпан» ${ }^{3}$.

Вместе с тем узость тематики имеет и свою положительную сторону, она говорит об увлеченности автором определенной стороной жизни. В конце XIX века приобретает невиданную остроту проблема пола, рождается гендерная психология. Шаврову интересует не только социальная проблема женской невостребованности в обществе, но и женская психология, мир женщины в целом. Уже первый, отредактированный Чеховым, рассказ $C o$ фка был посвящен девичьим переживаниям. Героине пятнадцать лет (как и автору), мать взяла ее на пикник, ее только что поцеловал в губы чужой мужчина, ей исповедуется в любви к уехавшей из Кисловодска «княгине» молодой грузинский князек:

\footnotetext{
${ }^{1}$ См.: П. С. Попов, Рассказ Е. М. Шавровой «Софка», [в:] Литературное наследство. Чехов, Москва: Изд-во АН СССР 1960, т. 68, с. 836-844 («Новое время» 1889, № 4846, 26 августа).

${ }^{2}$ См.: РГБ, ф. 331, к. 63, ед. хр. 4 а-к. 42 письма Шавровой были опубликованы в книге: Переписка А. П. Чехова. В 3-х тт., Москва: Наследие 1996, т. 2, с. 194-274.

${ }^{3}$ А. П. Чехов, Полное собрание сочинений и писем в 30-ти томах. Письма, Москва: Наука 1973-1984, т. 6, с. 144.
} 
Софка слушает молча и вдруг неожиданно начинает плакать, вся содрогаясь своим худеньким телом. Ей становится жаль этого хорошенького мальчика, жаль себя, жаль еще чего-то, чего она не могла бы объяснить словами, но что особенно больно мучает её в эту светлую ночь и заставляет плакать ${ }^{4}$.

Потребность в любви - основная в жизни человека, но кого любить молодой девушке, если вокруг одни некрасивые и неинтересные представители противоположного пола? Вот учитель географии в рассказе Замуж: «человек лет тридцати восьми, некрасивый и робкий. Он честен, добр и благороден, но нестерпимо скучен» ${ }^{5}$. Молодой девушке хочется «радости, любви, счастья, - жизни». Но замуж она может выйти только за Никитина!

Когда героине рассказа Маленькая барышня исполнилось 22 года, «она внезапно почувствовала какую-то пустоту тут и тут, то есть в сердце и в голове, и стала чудить». Героиня «была миниатюрная, стройная, аккуратно сложенная. У нее было совсем детское личико, мягкое, доброе, которое так и хотелось расцеловать. Ей делали предложение несколько раз, но она все отказывала» ${ }^{6}$. Однако замужество - единственный способ хоть как-то изменить свою жизнь, и героиня Шавровой выходит за «блестящего офицера, хорошей фамилии, с прекрасными манерами и с волчьим аппетитом, который он надеялся утолить приданым маленькой барышни». Отсутствие любви в жизни героиня Шавровой заменяет книгами, она «прочла почти всего Золя, Додэ, Мопассана, Флобера». В момент венчания на «хорошеньком, детском личике» застыло «не то испуганное, не то недоумевающее выражение [...] Выражение, точно говорившее: что они со мною делают? Господи, что они со мною делают» ${ }^{7}$

Состояние скуки, женского одиночества находим и в рассказе Птички певчие. У актрисы Поленьки «небольшой, звонкий голосок, настоящий, опереточный, но выпускают её нечасто, да и то в маленьких ролях» ${ }^{8}$. Ей нравится баритон Борисов, в описании которого автор подчеркивает маскулинность:

У знаменитого гастролера загорелая, мускулистая шея; ее красиво оттеняет ярко-красная рубашка, завязанная шелковым шнурком у ворота. [...] Хорош он бесспорно; красота у него настоящая, гастролерская, нахально-животная, на которую так падки женщины всех возрастов и положений (с. 223).

\footnotetext{
${ }^{4}$ Литературное наследство. Чехов..., т. 68. с. 844.

${ }^{5}$ Е. М. Шаврова [Е. Шастунов], Замуж, «Новое время» 1891, № 5348, с. 2.

${ }^{6}$ Е. М. Шаврова [Е. Ш.], Маленькая барышня, «Новое время» 1892, № 5746, с. 2.

${ }^{7}$ Там же.

${ }^{8}$ Е. М. Шаврова, Птички певчие, [в:] Спутники Чехова, Москва: Изд-во МГУ 1982, с. 222.
} 
Гастролер обращает внимание на хорошенькую блондинку и после спектакля приглашает ее покататься. Но он днем выпил вина и в коляске засыпает, положив голову на колени Поленьке. «Поленьке хорошо, тепло... жутко и весело... Она рада бы всю свою жизнь ехать так и держать на коленях голову, от которой пахнет сигарами и красным вином» (с. 226). После возвращения в Ялту баритон отправляется спать. «Только-то?» - думает Поленька (с. 226).

Мотив несбывшихся женских ожиданий в этом рассказе Е. М. Шавровой, возможно, подскажет Ив. Н. Ладыженскому название его рассказа'. В призведении Ладыженского проходит месяц после свадьбы, и молодым становится скучно. Муж возвращается к прежнему образу жизни в клубе, а жена изменяет ему. Но через три месяца любовник, прощаясь, «бесстрастно и противно» поцеловал Вашенцову. «“Только-то”, - со скорбью подумала она. Да, только-то, если в основе отношений не настоящая любовь и духовное родство и близость, а одна страсть, мимолетное увлечение» - морализирует рассказчик.

Для молодого писателя важны ориентиры, и для Шавровой таким ориентиром был, безусловно, Чехов, его школа. Дело не только в советах и в редактировании, но и в общем влиянии чеховской картины мира. Так, в основе фабулы рассказов и повестей Шавровой лежат бытовые ситуации, повествование ведется «в духе и тоне» героя, отсутствуют прямые оценки, большое значение имеет категория времени. Особенно «чеховскими» являются рассказы Маркиза и Жена цеезаря. О Маркизе Чехов писал:

Рассказ мне очень понравился, в нем кроме таланта, который и ранее не подлежал сомнению, чувствуется также ещё зрелость. Только заглавие показалось мне несколько изысканным. Фигура героини сделана так просто, что прозвище «маркиза» является какой-то лишней прицепкой, все равно как если бы Вы продели сквозь губу золотое кольцо. Если бы не было этого прозвища и если бы Нелли звали Дашей или Наташей, то финал рассказа вышел бы сочнее, а герой пухлее... ${ }^{10}$.

Маркиза напоминает отчасти чеховский рассказ Именины: в центре женский характер, любовь жены к мужу, ее ревность, подслушивание, из которого она узнает, что муж ее не любит, а любит молодую девушку Нелли. Есть друг дома, который всю жизнь любил маркизу и поэтому не женился. Женские переживания связаны с мужем, с семьей, с домом, т. е. они типичны для мира женщины в целом. Поиски Шавровой шли в сторону гендерной психологии, а не гендерной социологии. Вот героиня размышляет:

\footnotetext{
${ }^{9}$ Ив. Н. Ладыженский, Только-то (картинка с натуры), «Московская иллюстрированная газета» 29 марта 1892, с. 1.

${ }^{10}$ А. П. Чехов, Полное собрание сочинений и писем. Письма, Москва: Наука 1977, т. 5, c. 336 .
} 
Ну, что же делать, если она так глупо сотворена, что привязалась к человеку, с которым прожила восемь лет, имела детей, знала все его слабости и недостатки и все-таки любила его настолько сильно, что на всё была готова, лишь бы удержать его возле себя ${ }^{11}$.

Муж героини увлечен театром, хочет стать актером, он исповедуется молодой девушке:

Восемь лет я был работником для жены и детей. А что я видел? Что испытал? Что взял от жизни? Я не жил, а прозябал, как червь! Чем другие заканчивают свою жизнь, тем я начал. И вся жизнь моя пошла навыворот, наизнанку. Я не был молод, Я не жил! Я хочу жить ${ }^{12}$.

То, что переживает у Шавровой герой-мужчина принято называть в психологии «кризисом среднего возраста». Перед нами также классический случай проекции, т. е. «переносить собственные ошибки и ответственность за то, что происходит внутри „Я”, на других и окружающую среду»13. Финал рассказа, как и у Чехова, открытый.

В повести Жена цезаря в центре тоже женский персонаж. Героиню зовут Варвара Александровна, но все ее называют детским прозвищем Вава. Она выходит замуж за чиновника Сергея Павловича, который делает блестящую карьеру и даже получает придворное звание, «дававшее Ваве права приезда ко двору» ${ }^{14}$. Как и у Чехова, в повести Шавровой мало внешних событий: поездка героини в Москву к матери и к сестрам, болезнь героини, приезд друга детства Андрея в Санкт-Петербург, измена мужу с ним. Как и Чехова, Шаврову интересует внутреннее событие, изменение мирочувствия, крушение иллюзий. Молодой писатель воссоздает бытовое течение жизни, в которой нет никаких перемен. Героиню мучает «неотступная, навязчивая мысль: “Неужели всегда, всегда так будет? Изо дня в день? Без жизни, без перемены, без счастья? Так до самой могилы?"15.

Казалось бы, любовь Андрюши открывает возможность новой жизни:

Он даст развод, - говорил между тем Андрюша горячо и скоро. - Он обязан дать его, и мы женимся. Мы уедем отсюда навсегда. За границу, в деревню, в Москву, - куда хочешь... Нужно уйти от этой узкой, официальной, лживой жизни и зажить как-нибудь совсем по-новому... ${ }^{16}$.

11 3. С. Паперный, Тайна сия... любовь у Чехова, Москва: Изд-во Б.С.Г.-ПРЕСС 2002, с. 152.

${ }^{12}$ Там же, с. 312.

${ }^{13}$ Психология личности. Учебное пособие, под ред. П. Н. Ермакова, В. А. Лабунской, Москва: Эксмо 2008, с. 46.

${ }^{14}$ Писатели чеховской поры. В 2-х тт., Москва: Художественная литература 1982, т. 2 , c. 339 .

${ }^{15}$ Там же, с. 334.

${ }^{16}$ Там же. 
Но жена достойна своего цезаря, она не готова к разрыву с мужем, но готова к браку втроем. Чехов в письме к Шавровой высоко оценил рассказ: «Зато рассказ очень, очень понравился. Это хорошая, милая, умная вещь» ${ }^{17}$. Он дал автору ряд советов, большинство из которых были учтены.

3. С. Паперный писал:

(Жена цезаря). Он написан в традициях чеховской школы [...] Написан рассказ вполне литературно, но от него веет духом «вторичности». Читаешь и в то же время испытываешь ощущение, что это уже было, уже читано. В образе супруга Вавы многое напоминает Каренина из толстовского романа. Что же касается громоздящихся подробностей, о которых писал Чехов в письме Е. М. Шавровой после чтения рукописи, то, надо сказать, Елена Михайловна прислушалась к отзыву писателя и многое в рассказе сократила. Рассказ стал более компактным, не таким растянутым, но почти неуловимый дух эпигонства всё равно остался ${ }^{18}$.

После революции 1917 г. Шаврова - член Ленинградского общества драматических и музыкальных писателей, член Всероссийского союза писателей. Служила «секретаршей в Наркомпроссе, преподавала иностранный язык в Академии Красной Армии и Флота, переводчицей в издательстве „Всемирная литература”» ${ }^{19}$. Под фамилией мужа (Елена Юст) были опубликованы несколько ее переводов (У. Д. Локк, Великий Пандольфо, Ленинград: Мысль 1926; У. Д. Локк, Старый мост, Ленинград: Мысль 1927; У. Д. Локк, Мечта Джошуа, Киев: Культура 1929; У. Д. Локк, Счастье Теофила, Ленинград: Мысль 1929; Р. Хиченс, На экране, Ленинград: Время 1928). Писательница пыталась опубликовать в «Красной панораме» перевод рассказа С. Моэма Хитрость моего друга Роджера ${ }^{20}$. Шаврова печаталась редко (зарисовка Женские силуэты. Genre Artiste в журнале «Столица и усадьба» 1917, № 74). Три очерка в журнале «Огни» не были опубликованы ввиду закрытия журнала, в том числе очерк $O$ Чехове. В 1919 г. с Шавровой встречался К. И. Чуковский ${ }^{21}$.

В 20-е и 30-е годы Шаврова переписывалась с М. П. Чеховой и М. П. Чеховым. В письме к М. П. Чеховой от 17.06.1924 г. сообщала:

Недавно я окончила свои воспоминания об Антоне Павловиче, и посвятила их Вам, - если Вы разрешите мне это. Эти воспоминания приняты к напечатанию в предполагаемом сборнике Чеховского музея в Москве ${ }^{22}$.

\footnotetext{
${ }^{17}$ А. П. Чехов, Полное собрание сочинений..., т. 6, с. 232.

18 3. С. Паперный, Тайна сия... любовь у Чехова..., с. 152.

${ }^{19}$ РНБ, фонд № 103, архив Бродерсен Г. Г., ед. хр. 163.

${ }^{20}$ РО ИРЛИ, ф. 355, ед. хр. 62. Архив Л. И. Аверьяновой.

${ }^{21}$ См.: К. И. Чуковский, Дни моей жизни, Москва: Бослен 2009, с. 156.

${ }^{22}$ РГБ.Ф 331, к. 98, ед. хр. 88.
} 
Но эпопея с публикацией тянулась много лет, они были опубликованы уже после смерти ${ }^{23}$. Полностью воспоминания Е. М. Шавровой $B$ стране минувщего. Воспоминания и встречи за сорок лет, охватывающие период с детских лет по 1933 не опубликованы до сих пор.

\section{References}

Chekhov, Anton P. Polnoe sobranie sochinenii i pisem v 30-ti tomakh. Moskva: Nauka, 1973-1984. Chukovskii, Kornei I. Dni moei zhizni. Moskva: Boslen, 2009.

Ladyzhenskii, Ivan N. "Tolko-to (kartinka s natury)". Moskovskaya illyustrirovannaya gazeta, 29 marta 1892.

Literaturnoe nasledstvo. Chekhov. Moskva: Izd-vo AN SSSR, 1960. Vol. 68.

Papernyi, Zinovii S. Taina siya ... lyubov u Chekhova. Moskva: Izd-vo B.S.G.-PRESS, 2002.

Perepiska A. P. Chekhova. V 3-kh tt. Vol. 2, Moskva: Nasledie 1996: 194-274.

Pisateli chekhovskoi pory. V 2-kh tt. Moskva: Khudozhestvennaya literatura, 1982. Vol. 2.

Popov, Pavel S. Rasskaz E. M. Shavrovoi "Sofka". In. Literaturnoe nasledstvo. Chekhov. Vol. 68, Moskva: Izd-vo ANSSSR 1960: 836-844.

Psikhologiya lichnosti. Uchebnoe posobie, ed. P. N. Ermakova, V. A. Labunskoi. Moskva: Eksmo, 2008. Shavrova, Elena M. [E. Sh.]. "Malenkaya baryshnya". Novoe vremya, No. 5746 (1892).

Shavrova, Elena M. [E. Shastunov]. "Zamuzh". Novoe vremya, No. 5348 (1891).

Shavrova, Elena M. Ptichki pevchie. In: Sputniki Chekhova. Moskva: Izd-vo MGU 1982.

Shavrova-Yust,Elena M. Moi vstrechi s Antonom Pavlovichem. In: Literaturnyi muzei A. P. Chekhova. Sbornik statei i materialov. Rostov-na-Donu: Rostovskoe knizhnoe izd-vo., 1963.

Sputniki Chekhova. Moskva: Izd-vo MGU, 1982.

${ }^{23}$ Е. М. Шаврова-Юст, Мои встречи с Антоном Павловичем, [в:] Литературный музей А. П. Чехова. Сборник статей и материалов, Ростов-на-Дону: Ростовское книжное изд-во 1963, c. 267-309. 